\title{
Molecular dissection of human B-cell tolerance - insights from patients with rare genetic diseases
}

\author{
Henner Morbach ${ }^{1,2^{*}}$, Greta Meyers ${ }^{2}$, Yen-Shing $\mathrm{Ng}^{2}$, Jean-Nicolas Schickel ${ }^{2}$, Laurence Menard', Sergei Rudchenko ${ }^{3}$, \\ Jessica L Rojas ${ }^{4}$, Charlotte Cunningham-Rundles ${ }^{5}$, Mary Ellen Conley ${ }^{6}$, Ismail Reisli, Jose Luis Franco ${ }^{4}$, Eric Meffre ${ }^{1}$ \\ From 50th Workshop for Pediatric Research \\ Gottingen, Germany. 20-21 March 2014
}

B cells play a central role in the pathogenesis of many autoimmune diseases. Therefore, understanding the mechanisms that regulate B-cell tolerance in humans is important for the development of new therapeutic strategies. Patients with monogenic diseases provide rare opportunities to study the impact of specific gene mutations on the regulation of human B cell tolerance. By this, we could show that alterations in B-cell receptor and Toll-like receptor (TLR) signaling pathways result in defective central B-cell tolerance.

To further dissect the signaling pathways involved in the establishment of central B-cell tolerance in humans, we tested by ELISA and immunofluorescence the reactivity of recombinant antibodies cloned from single transitional $\mathrm{B}$ cells from individuals carrying CD19 mutations. CD19 is a co-receptor expressed on $\mathrm{B}$ cells and is involved in the amplification of B-cell responses.

We found that individuals carrying $C D 19$ mutations displayed defective central B-cell tolerance checkpoints. In addition, CD19-deficient transitional B cells were enriched in anti-nuclear clones, a feature previously observed in IRAK4- and MYD88-deficient patients in which TLR7/9 sensing nucleic acids cannot signal. Therefore, we investigated the functions of these TLRs in B cells in the absence of CD19 expression. CD19-deficient human B cells displayed defective up-regulation of activation markers after TLR7/9 triggering and failed to induce BTK, AKT but not $\mathrm{p} 38$ MAPK or $\mathrm{I} \kappa-\mathrm{B} \alpha$ phosphorylation after TLR7/9 stimulation. Additionally, inhibitors blocking BTK, AKT and PI3K function impaired CD19-dependent TLR7/9 responses in healthy donor's B cells. Finally, we demonstrated that individuals carrying $B T K$ mutations display

${ }^{1}$ University Children's Hospital, Würzburg, Germany

Full list of author information is available at the end of the article similar defects in TLR7/9-induced B-cell activation and central B-cell tolerance.

Hence, we identified a previously unsuspected role for CD19 molecules in regulating TLR7/9 functions in human $\mathrm{B}$ cells and central B-cell tolerance to nuclear antigens.

\section{Authors' details}

'University Children's Hospital, Würzburg, Germany. ${ }^{2}$ Department of Immunobiology, Yale University School of Medicine, New Haven, CT, USA. ${ }^{3}$ Laboratory of Biochemistry and Molecular Immunology, Hospital for Special Surgery, New York, NY, USA. ${ }^{4}$ Group of Primary Immunodeficiencies, University of Antioquia, Medellín, Colombia. ${ }^{5}$ Department of Medicine, Mount Sinai Medical Center, New York, NY, USA. ${ }^{6}$ Department of Pediatrics, University of Tennessee College of Medicine, Memphis, TN, USA.

${ }^{7}$ Department of Immunology and Allergy, Meram Medical Faculty, Selcuk University, Konya, Turkey.

Published: 11 September 2014

\section{doi:10.1186/2194-7791-1-S1-A16}

Cite this article as: Morbach et al: Molecular dissection of human B-cell tolerance - insights from patients with rare genetic diseases. Molecular and Cellular Pediatrics 2014 1(Suppl 1):A16.

Submit your manuscript to a SpringerOpen ${ }^{\bullet}$ journal and benefit from:

- Convenient online submission

- Rigorous peer review

- Immediate publication on acceptance

- Open access: articles freely available online

- High visibility within the field

- Retaining the copyright to your article

Submit your next manuscript at $\boldsymbol{\nabla}$ springeropen.com

\section{SpringerOpen ${ }^{\circ}$}

( 2014 Morbach et al; licensee Springer This is an Open Access article distributed under the terms of the Creative Commons Attribution License (http://creativecommons.org/licenses/by/2.0), which permits unrestricted use, distribution, and reproduction in any medium, provided the original work is properly cited. 